\title{
The Answer is to Question
}

\author{
Kevin Johnston \\ University of Cape Town, Cape Town, South Africa
}

kjohnsto@commerce.uct.ac.za

\begin{abstract}
"What did you learn in school today, dear little boy of mine?" asked the lyrics of satirist Tom Paxton a generation ago. "I learned our government must be strong./ It's always right and never wrong..../ That's what I learned in school today." (A full set of lyrics appears at the end of the paper).

Should the role of our classrooms be to serve as dumping grounds for tired old theories, or as launching pads for unfettered inquiries into new exciting worlds? Should we continue to throw out theory and facts, and set answers, or should we embark on a never-ending quest for new questions and insights?

On obtaining a degree or diploma, each student should know how to answer questions, but how many know how to ask questions? What would they say when asked "what did you learn in school today?"
\end{abstract}

Keywords: enroll, teach, learn, question, relevance.

\section{Introduction}

This paper questions what is taught, how it is taught, by whom, to whom, and what is learnt in educational institutions.

"Schools without a strong commitment to student questioning and research are wasting their money...As long as schools are primarily about teaching rather than learning, there is little need for expanded information capabilities. Considering the reality that schools and publishers have spent decades compressing and compacting human knowledge into efficient packages and delivery systems like textbooks and lectures, they may not be prepared for this New Information Landscape which calls for independent thinking, exploration, invention and intuitive navigation" (McKenzie, 1997).

The paper concludes with some alternatives, some suggestions for teachers, and some questions for teachers. Students should be taught how to ask relevant and appropriate questions.

"Once you have learned how to ask relevant and appropriate questions, you have learned how to learn and no one can keep you from learning whatever you want or need to know" (Postman \& Weingartner, 1977).

The answer is to question, and to keep questioning. Teachers and students must forever question.

\section{What is the Purpose of Education?}

Material published as part of these proceedings, either on-line or in print, is copyrighted by Informing Science. Permission to make digital or paper copy of part or all of these works for personal or classroom use is granted without fee provided that the copies are not made or distributed for profit or commercial advantage AND that copies 1) bear this notice in full and 2) give the full citation on the first page. It is permissible to abstract these works so long as credit is given. To copy in all other cases or to republish or to post on a server or to redistribute to lists requires specific permission from the publisher at Publisher@InformingScience.org
What is the purpose of education? I submit it is twofold

- To expand to the limit the individuals capacity, and desire, for self education (to create life-long learners), for seeking and finding meaning, truth and enjoyment in everything he or she does, and 


\section{The Answer is to Question}

- To increase the survival prospects of the group to which the individual belongs

Do our Schools and Universities expand the minds of our students, or do we restrict them to out-dated compartmentalized syllabi?

Do we teach students to question, or to be questioned? Do we teach students discovery or what has been discovered?

Do we teach students to seek truth even if it does not serve our cause?

Do we teach students enjoyment and passion, or do we teach routine, fear and anxiety?

Do we teach students to survive, to adapt to change, or do we teach them to conserve old ideas, concepts and attitudes?

Most of our students fail at some point. The best may only fail to develop more than a tiny part of the tremendous capacity for learning, understanding and creating with which they were born, which they used to the full in the first few years of life.

Most students are afraid of failing (see how many turn up when discussing exams), of disappointing parents/teachers, and of not pleasing or not doing what other people want them to do. Most are afraid of making mistakes, of being wrong, of looking foolish, of standing out. Many are afraid to experiment, to try different and unknown things, afraid to be different.

Many students are bored, they are given tasks which are trivial, dull, and make such a limited and narrow demand on their intelligence, capabilities and talents - they are encouraged to work for petty and contemptuous rewards - gold stars, marks, i.e. for the ignoble satisfaction of feeling better than someone else (Postman \& Weingartner, 1977).

Many of our students are confused. Words make little or no sense to them, there is little relation to reality - many of our IS students have no idea of what a server is. They feel that the end aim is nothing more than to get a good mark. We kill curiosity and the feeling that it is good to be curious, to ask questions.

Schools destroy our youth. Where would we expect workers (students) to work for 6 different bosses in one week, in several different workgroups, to have no desk of their own, to be always on the move?

What sensible organization would forbid its workers to ask their colleagues for help, would expect them to carry all relevant facts in their heads, would require them to work for 45 minute spells and then to move to a different site, would work them in groups of 100-200 and prohibit any social interaction except at official break times?

\section{Who Enrolls and Why?}

Who are the people who enroll, and why do they do so? Milliken and Barnes (2002) state that the stur dent population has "diversified in terms of age, gender, ethno-religious background and socioeconomic profile," in the United Kingdom over the past few decades. This is probably a global phenomenon. What do these people look like in terms of amb ition, ability, background, age, and gender? Why do they erroll, is it due to pressure from parents, lack of job opportunities, fear of open market, to enjoy a social life or because they can?

\section{How do Students Rate Teachers?}

A study by Hart, Adams et al (2001) revealed that students rated Teachers as the lowest influence in selecting a career. Computers at home, media, friends, other, parents, career development centers were all rated higher. Why are teachers rated so lowly?

"Schootdays, I believe, are the unhappiest in the whole span of human existence. They are full of dull, unintelligible tasks, new and unpleasant ordinances, brutal violations of common sense and common 
decency. It doesn't take a reasonably bright boy long to discover that most of what is rammed into him is nonsense, and that no one really cares very much whether he learns it or not, "(Mencken, 1928). Does this still hold true?

\section{Who Teaches and Why?}

Who are the lecturers at University, what are their backgrounds, abilities, ambitions etc? Why are they lecturing, because it is stimulating, fun, pays extremely well, can't get any other job, or because it is a calling? What is the role of a lecturer, to induce new knowledge into the knowledge systems of students, or to coax students existing knowledge systems out of hiding? Should teachers be subversive?

I challenge you to ask yourself the question, "Why am I a teacher?" I then challenge you to give yourself an honest answer and to reflect on that answer.

How do we get to know whatever we think is worth knowing? Did we learn it, was it taught to us, or did we discover it? How do we expect our students to get to know worthwhile things?

A teacher job is to induce new knowledge into the existing knowledge systems of students. This is a difficult job, as is often not welcomed by the students. A possible reason is that having to learn new know ledge, means existing knowledge is challenged. A true teacher is someone who can get students to change their existing knowledge systems (Postman \& Weingartner, 1977). How open to change are teachers? Research by Baylor \& Ritchie (2002) found that teachers, who were open to change, help students learn and develop thinking skills.

Apart from the normal incentives, the morale of teachers can be lifted by creativity and satisfaction (Baylor \& Ritchie, 2002) in the classroom. The question is how can teachers be creative?

\section{How and What is Taught?}

Lectures, textbooks and a few tutorials are generally the methods used to deliver new knowledge to students. Theory with unrealistic examples is examined. There have always been questions at universities, but most of them come from the teachers, and most tend to require recall, rather than requiring higherlevel thought (McKenzie, 1997). Teachers need to vary their teaching methods (Boekaerts, 2002) and not stick to single models such as outcomes-based or learning acquisition models. Boekaerts (2002) states that teachers need to liberate themselves from content-driven theories of teaching, to contextdriven theories. Teachers' attitudes need to change (Blanton, 2002; Baylor \& Ritchie, 2002), from expert to facilitator.

Think about the fact that people taught that the Earth was flat, that kings were superior beings, COBOL was 'the' programming language, PC's were playthings and not for serious use, that women were inferior to men. Now ask how much of what we teach today will be laughed at in years to come.

Traditional teaching methods have served the interests of teachers and institutions more than the interests of students (Milliken \& Barnes, 2002).

\section{How do you Learn?}

"You learn by what you see, what you hear, what you taste, what you smell, what you touch, what you do, what you imagine, what you intuit, what you feel" (Dryden \& Vos, 1997). The average person learns $15 \%$ of what they hear, $10 \%$ of what they read, and $80 \%$ of what they experience, so how should we teach?

Reflection is an important and often neglected part of learning. Reflection is a difficult process as it questions personal prestige, decisions made, roles and actions (Wissema, 2002). Western culture en- 


\section{The Answer is to Question}

courages us to be individ ualistic and to try to do everything alone (Wissema, 2002), but reflection can lead to new insights and learning.

"The scientific mind does not so much provide the right answers as ask the right questions" LéviStrauss(1964).

\section{What should we do?}

It is proposed that teachers should have courage (Hare, 2002), and re-examine themselves, and their roles. Teachers should adopt a questioning toolkit (McKenzie, 1997) that is used in every course. Stur dents should be taught how to ask relevant and appropriate questions.

"Once you have learned how to ask relevant and appropriate questions, you have learned how to learn and no one can keep you from learning whatever you want or need to know," (Postman \& Weingartner, 1977).

Some ideas of what to do:

1. Pursue relevance - what is worth knowing? What is it good for? When will we ever need this? How do I know? Every teacher should ask him/herself these questions every day (Postman \& Weingartner, 1977; Blanton, 2002; Yackel, 2002).

2. Confront students with a relevant interesting problem in some lectures - allow them to work without your advice or suggestions. If asked a question, say you do not know the answer even if you do - answers can restrict thinking (Blanton, 2002) and learning, questions can stimulate it. Shift the burden of intellectual activity to the students (Postman \& Weingartner, 1977). Make students work in small groups for short periods (2-5 minutes) to "think about" a question or issue (Yackel, 2002), then get the whole class to discuss the groups reasoning and arguments.

3. Listen to students, and make them listen to each other (Blanton, 2002). Engage students in a disc ussion with an unusual rule - anyone may say anything they want to say, provide that they first restate what the previous person said to that persons satisfaction. This forces students to practice and develop listening skills. By listening to students teachers may discover what students perceive as relevant (Postman \& Weingartner, 1977).

4. Inquiry method. Ensure that it becomes routine for students to question and challenge everything in class (Blanton, 2002; Yackel, 2002). Force students to ask questions, set tutorials/exams where they have to ask questions. At the University of Cape Town (UCT) we put such questions in tutorials and exams. We give bonus marks for good questions asked in class. How does one evaluate questions? Does question contain unwarranted assumptions, have undefined terms, suggest an answer, clear/unambiguous, challenging, difficult, thought provoking, analytical, does it lead to problem solving, to decision making. The simple why, how and which produce relevant questions. Without strong questioning skills, students are unlikely to be able to survive information overload, and navigate the all the information thrown at them. Students with weak questio ning skills are less likely to discover value and truth. Teachers should develop Questioning Too 1kits. These Questioning Toolkits should contain several kinds of questions and questioning tools. Essential Questions, Elaborating Questions, Chrification Questions, Irrelevant Questions, Irre verent Questions Hypothetical Questions Unanswerable Questions Strategic Questions Provocative Questions Telling Questions Divergent Questions Probing Questions Inventive Questions Planning Questions (MacKenzie, 1997).

5. Pygmalion principle 'self-fulfilling prophecy'- imagine your students have unlimited potential, and act accordingly. Act as if they are all capable of great things, because they are (Postman \& Weingartner, 1977). 
6. Look forward; ask questions about the future. There are many professors of history, why are there no professors of the future, after all the future is more important to us than the past. We ask questions about the future in class and in exams, such as what do you think the effects of mobile IT applications will have on society?

7. Look broadly, do not think or lecture only in terms of your field. Include bits about other courses they are doing, philosophical bits such as ethics, bits about the media, and bits about English, Math, and TV etc.

8. Process not product is important. Students get a degree in IS, but have never seen a huge server. Don't get hung up on syllabi. Learn golf by golfing, learn to walk by walking, learn best by doing it. "We see what we understand rather than understand what we see" (Labinowicz, 1985).

9. Failure can be honorable if constructive, and failure is part of life (Postman \& Weingartner, 1977; Wissema, 2002).

10. Allow each student to satisfy his/her curiosity (Postman \& Weingartner, 1977).

11. Allow each student to develop his/her abilities and talents.

12. Allow each student to pursue his/her interests. Allow third years to choose any essay topic they like.

13. Find fun in teaching and learning (Blanton, 2002), make the classroom a fun place to be for all. Ensure that there is an amount of play in the classroom. We sometimes use props such as toys to illus trate a point, or to stimulate discussion. For example students were asked why they thought the lecturer had a fluffy duck in class when discussing Customer Relation Management (CRM). The students came up with amazing ideas and insights about customer relationships. Like Blanton (2002) costumes and dress can be used for effect, for instance wearing a suit when discussing serious subjects such as strategy and finance.

\section{Conclusion}

This paper has questioned what is taught, how it is taught, by whom, to whom, and what is learnt in ed ucational institutions. Several practical ideas as to what teachers could do in classrooms were put forward for consideration. So, what are you going to do now?

\section{References}

Baylor AL \& Richie D, (2002). What factors facilitate teacher skill, teacher morale, and perceived student learning in technology-using classrooms? Computers \& Education, Volume 39, Issue 4, Pages 395-414.

Blanton P, (2002). All I need to know about teaching I learned from my students. The Physics Teacher, Volume 40, Pages 557-558.

Boekaerts M, (2002). Bringing about change in the classroom: strengths and weaknesses of the self-regulated learning approach - EARLI Presidential address, 2001. Learning and Instruction, Volume 12, Issue 6, Pages 589-604

Dryden G \& Vos J, (1997). The Learning Revolution. The Learning Web Ltd, Auckland, New Zealand, ISBN 0-9583701-0-9

Hare W, (2002). Ideas for Teachers: Russell's legacy. Oxford Review of Education, Volume 28, Issue 4, Pages 491-510

Hart M, Adams K, Menziwa L and Pretes E (2001). Student Perceptions of Information Systems Careers. Unpublished Ho nours research paper, UCT

Labinowicz E (1985). Learning from Children. Menlo Park, CA: Addison-Wesley Publishing Company

Lévi-Strauss C (1964). The Raw and the Cooked, “Overture.” sct. 1.

Mencken HL, (1928). Travail. in Baltimore Evening Sun (8 Oct. 1928) 


\section{The Answer is to Question}

McKenzie J, (1997). The Question is the answer - Creating Research Programs for An Age of Information. Retrieved November 19, 2002 from the World Wide Web http://www.fno.org/oct97/question.html

Milliken J \& Barnes L.P (2002). Teaching and technology in higher education: student perceptions and personal reflections. Computers \& Education, Vol 39, Issue 3, Pages 223-235

Paxton T, (1963). What did you learn in school today. Copyright Cherry Lane Music Publishing Co., Inc

Postman N \& Weingartner C, (1977) Teaching as a subversive activity. Penguin Education

Wissema H (2002). Driving through red lights. How warning signals are missed or ignored. Long Rang Planning, Vol 35, Issue 5, pages 521-539

Yackel E (2002). What we can learn from analyzing the teacher's role in collective argumentation. The Journal of Mathematical Behaviour, Article in Press, uncorrected proof

\section{Biography}

Kevin Johnston was born in Umtata, Transkei, South Africa in 1953. He obtained a B.Sc from Rhodes University, a B.Sc (Hons) from the University of South Africa (UNISA), and an M.Com from the University of Cape Town (UCT). Kevin is married with two daughters. Kevin has over 20 years of experience in the IT industry in Southern Africa, working for companies such as De Beers, Liberty Life and BoE. Kevin has spoken at IT conferences in Africa, Europe and the USA. He is currently a senior lecturer in Information Systems at UCT.

\section{Appendix}

\section{"What Did You Learn in School Today" a song by Tom Paxton}

What did you learn in school today, dear little boy of mine?

I learned that Washington never told a lie

I learned that soldiers seldom die

I learned that everybody's free

That's what the teacher said to me

And that's what I learned in school today

That's what I learned in school

What did you learn in school today, dear little boy of mine?

I learned that policemen are my friends

I learned that justice never ends

I learned that murderers die for their crimes

Even if we make a mistake sometimes

And that's what I learned in school today

That's what I learned in school

What did you learn in school today, dear little boy of mine?
I learned that war is not so bad

I learned about the great ones we have had

We fought in Germany and in France

And someday I might get my chance

And that's what I learned in school today

That's what I learned in school

What did you learn in school today, dear little boy of mine?

I learned that our government must be strong

It's always right and never wrong

Our leaders are the finest men

So we elect them again and again

And that's what I learned in school today

That's what I learned in school

Copyright Cherry Lane Music Publishing Co., Inc.

ID37 